\title{
NOW AVAILABLE
}

\section{CHURCH HISTORY INDEX, 1981-1990 \\ (Volume 4)}

Includes index of all articles by author, title, and subject and all book reviews by title, author index, and reviewer which were published in CHURCH HISTORY from 1981-1990

$$
275 \text { pages }
$$

$\$ 12.00$ (including postage)

A limited number of previously published volumes of the $\mathrm{CHURCH}$ HISTORY INDEX are still available at \$12.00 each including postage:

$$
\begin{aligned}
& \text { Volume } 1,1889-1961-\text { no longer available } \\
& \text { Volume 2, 1962-1970 - } 107 \text { pages } \\
& \text { Volume 3, 1971-1980 - } 179 \text { pages }
\end{aligned}
$$

Requests for copies, with covering remittance, should be forwarded to:

Henry W. Bowden

American Society of Church History

P.O. Box 8517

Red Bank, NJ 07701 


\section{APPLICATIONS INVITED FOR RESEARCH GRANTS IN MISSION AND WORLD CHRISTIANITY}

The Overseas Ministries Study Center, New Haven, Connecticut, U.S.A., administers the Research Enablement Program for the advancement of scholarship in studies of Christian Mission and Christianity in Asia, Africa, Latin America, and Oceania. Grants will be awarded on a competitive basis in the following categories:

\section{Postdoctoral book research and writing projects \\ Field research for doctoral dissertations \\ Small-scale missiological consultations \\ Planning grants for major interdisciplinary research projects}

The Research Enablement Program is designed to foster scholarship that will contribute to the intellectual vitality of the Christian world mission and enhance the worldwide understanding of the Christian movement in the non-Western world. Projects that are cross-cultural, collaborative, and interdisciplinary are especially welcome. The deadline for receiving 1997 grant applications is November 28, 1996. For further information and official application forms please contact:

Geoffrey A. Little, Coordinator

Research Enablement Program

Overseas Ministries Study Center

490 Prospect Street

New Haven, Connecticut 06511-2196, U.S.A.

Tel: (203) 865-1827

Fax: (203) 865-2857

E-mail: glittle.rep@OMSC.org

This program is supported by a grant from The Pew Charitable Trusts. 
Divisions among Christian communions have sometimes arisen from and are often sustained by vastly different accounts of the origins and development of important historical events. Telling the Churches' Stories takes a critical look at the practice of writing church history and challenges historians of Christianity to be self-consciously ecumenical in the practice of their craft. The essays in this volume evaluate and employ fourteen principles for writing Christian history from an ecumenical perspective.

Editors Timothy J. Wengert and Charles W. Brockwell, Jr., begin by placing these principles of historiography more fully within current trends in ecumenism and church history. In response,

Richard A. Norris critiques these principles, their moral basis, and the difficulties with their implementation, and Günther Gassmann places these principles squarely within the global context of ecumenical history.

Three noted historians, contributing articles from their own fields, apply these principles to specific case studies: Frederick W. Norris examines the Arian controversy of the fourth century; Elsie Anne McKee looks at Katharina Schütz Zell, an influential sixteenth-century Protestant Reformer; and James Hennesey investigates the

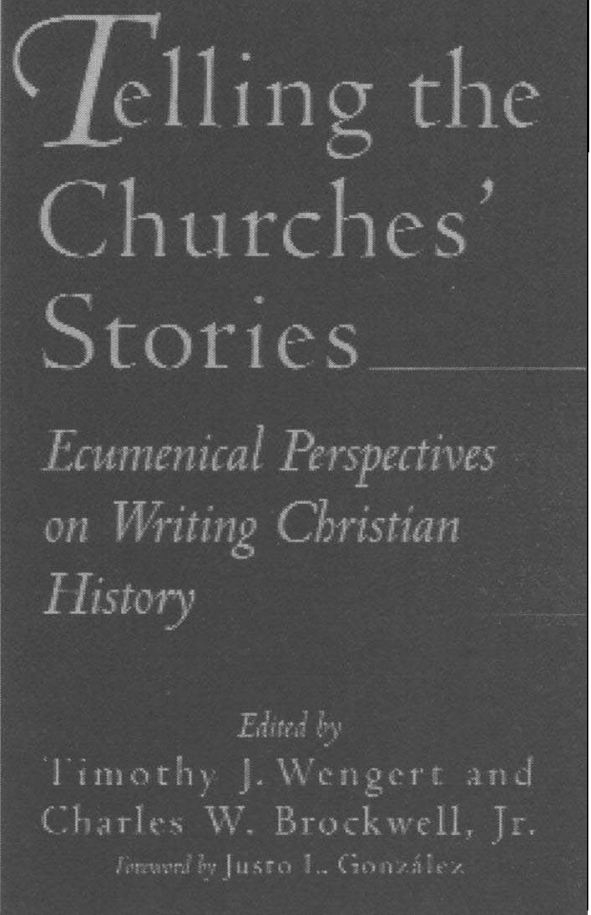

role of history in the nineteenthcentury Roman Catholic Church in the United States.

A foreword by Justo L. González, a conclusion by Thomas Finger, and a bibliographic essay by Douglas A. Foster also provide ample indication of the importance these principles will have for organizing meaningful discussion of the profound ways in which ecumenical perspectives and history writing interact with each other.

ISBN 0-8028-0556-6 $\bullet 156$ pages Paperback $\bullet \$ 15.00$ 


\section{PRIZES OF THE AMERICAN SOCIETY OF CHURCH HISTORY}

\section{The Frank S. and Elizabeth D. Brewer Prize}

The Frank S. and Elizabeth D. Brewer Prize, offered annually, is a subvention fund of $\$ 1000$ to assist a press in publishing a book-length manuscript in church history. The Brewer Prize is limited to first books. Manuscripts already accepted for publication may be submitted for this award, but the publication must have printed on its title-page, "The Frank S. and Elizabeth D. Brewer Prize Essay of the American Society of Church History." The monetary grant will be authorized upon receipt in writing of a commitment from a publisher accepting the manuscript. Complete manuscripts in final form must be received by Henry W. Bowden, P.O. Box 8517, Red Bank, NJ 07701, by 1 November. Manuscripts may not be submitted in more than one ASCH competition. The award will be announced at the Spring meeting of the Society. No award will be made in any year when none of the manuscripts is adjudged to be outstanding.

Winner for 1994: Stephen Burnett "From the Jews' Own Books: Johann Buxtorf, Christian Hebraism, and the Emergence of Jewish Studies."

Winner for 1993: Diana Hochstedt Butler, "Standing Against the Whirlwind: A Study of the Evangelical Party in the Protestant Episcopal Church."

Winner for 1992: Gregory Hanlon, "Confession and Community in SeventeenthCentury France: Catholics and Protestants in Acquitaine."

\section{The Philip Schaff Prize}

The Phllip Schaff Prize is an award in the amount of $\$ 1000$ to be paid to the author of the best book originating in the North American scholarly community which presents original research in the history of Christianity or any period thereof. This award is given in odd-numbered years. Books published during the two previous calendar years are eligible for the competition. Any member of the Society may nominate titles for consideration. Copies of nominated books need not be submitted. Titles of nominated books must be received by Henry W. Bowden, P.O. Box 8517, Red Bank, NJ 07701 by 1 March in odd-numbered years. The prize will be announced at the annual Winter meeting of the Society.

Winner for 1993: Stephen J. Stein, The Shaker Experience in America.

Winner for 1991: David D. Hall, Worlds of Wonder, Days of Judgment: Popular Religious Belief in Early New England.

\section{The Sidney E. Mead Prize}

The Sidney E. Mead Prize is an award in the amount of $\$ 250$ for the author of the best unpublished essay in any field of church history written by a doctoral candidate or recent recipient whose manuscript stems directly from doctoral research. The manuscript will be published in Church History. Entries of no more than twenty-five double-spaced pages, including double-spaced endnotes, must be submitted to Henry W. Bowden, P.O. Box 8517, Red Bank, NJ 07701, by 1 July. The prize is offered annually, though no award will be made in any year when none of the manuscripts is adjudged to be outstanding. Manuscripts may not be submitted in more than one ASCH competition. The winner will be announced at the annual Winter meeting of the Society.

Winner for 1992: Alison Williams Lewin, “'Cum Status Ecclesie Noster Sit . . . Florence and the Council of Pisa (1409)."

Winner for 1991: Ernest Freeburg, " 'An Object of Peculiar Interest': The Education of Laura Bridgman." 


\section{"This is the most comprehensive and most lucidly}

written introduction to the methods of historical research and writing in the field of church history that I have seen. . . A magnificent achievement." - Harry S. Stout

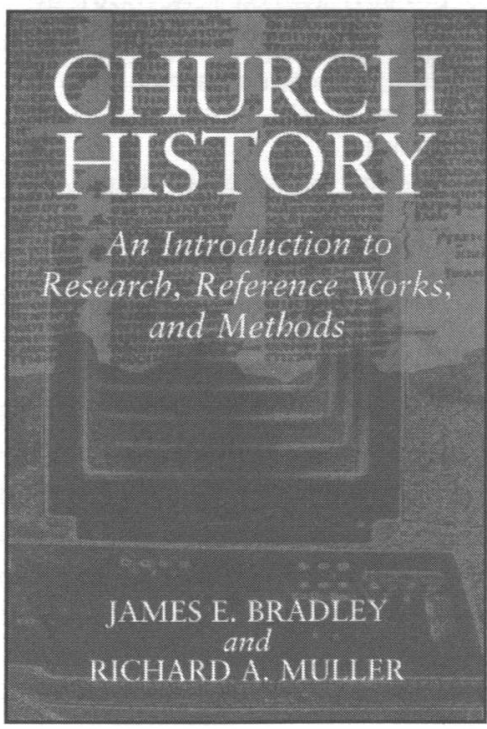

"This carefully prepared book is a very useful introduction to research and methods for the whole field of church history and historical theology, but it also contains rich information and insight for those researching or teaching any aspect of this vast subject. . . It effectively points out how to locate and use significant classics in the field and also how to make use of the cascading resources and powers of the computer. Neither dissertation writ ers nor those laboring on historical lectures, articles, or monographs should miss this book."

\section{- Robert T. Handy}

"Anyone beginning research in church history - as well as many old hands - will find this book to be the best single-volume resource for theory and practice, incorporating bibliographical information and guidance on computer aids."

- David Bebbington

ISBN 0-8028-0826-3 $\bullet 252$ pages $\bullet$ Paperback $\bullet \$ 19.00$

At your bookstore, or call 800-253-7521 • FAX 616-459-6540 


\section{THE ALBERT C. OUTLER PRIZE IN ECUMENICAL CHURCH HISTORY}

The Albert C. Outler Prize in Ecumenical Church History consists of an award of $\$ 1000$ to the author of a book-length manuscript and a possible grant of up to $\$ 3000$ for publication costs-or in exceptional cases, for necessary expenses in the preparation of a manuscript accepted for publication. The term "Ecumenical" is to be construed as chiefly concerned with the problems of Christian unity and disunity (doctrinal, cultural, institutional) in any period of church history, or with interactions between Christianity and other religious movements. Works of a partisan nature are excluded. The winning manuscript must have printed on its title-page, "The Albert C. Outler Prize in Ecumenical History of the American Society of Church History." Complete manuscripts in final form must be received by Henry $W$. Bowden, P.O. Box 8517, Red Bank, NJ 07701, by 1 June. The prize is offered annually, though no award will be made in any year when none of the manuscripts is adjudged to be outstanding. Manuscripts may not be submitted in more than one ASCH competition. The winner will be announced at the annual Winter meeting of the Society.

Winner 1993: Allen C. Guelzo, For the Union of Evangelical Christendom: The Irony of the Reformed Episcopalians, 1873-1930.

Winner for 1991: Ronald L. Numbers, The Creationists.

\section{THE JANE DEMPSEY DOUGLASS PRIZE}

The Jane Dempsey Douglass Prize is an award in the amount of $\$ 250$ for the author of the best unpublished essay on some aspect of the role of women in the history of Christianity. The manuscript will be published in Church History. Entries of no more than twenty-five double-spaced pages, including doubled-spaced endnotes, must be submitted to Henry W. Bowden, P.O. Box 8517, Red Bank, NJ 07701, by 1 August each year. The prize is offered annually, though no award will be made in any year when none of the manuscripts is adjudged to be outstanding. Manuscripts may not be submitted in more than one ASCH competition. The winner will be announced at the annual Winter meeting of the Society.

Winner for 1993: Genevieve McCoy, "Post-Edwardian Calvinism and the Women of the ABCFM Oregon Mission."

Winner for 1991: Joyce Irwin, "Pietism and Women: A Study in Contrasts." 
Cosmos

Chaos

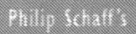

interometanton

Winclectith.

cemitivis

Anerican

Relizizan

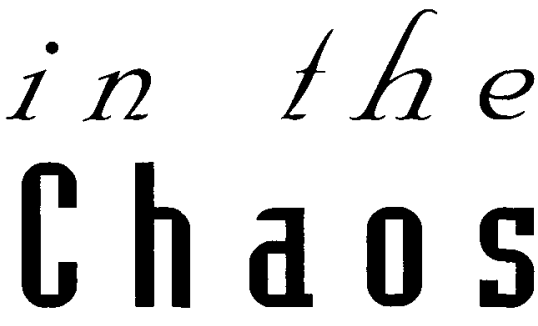

fosmos

"In this excellent volume Stephen Graham has made his own unique contribution to the literature on Philip Schaff. Graham has written the most complete interpretation available of Schaff's views and vision of nineteenth-century American religion.... Our own contemporary religious issues will be informed by this creative presentation of Schaff and his hopes for his adopted homeland, which included Christian cosmos, point omega of unity."

- George H. Shriver

"A welcome contribution to the growing body of literature on Philip Schaff. ... No one has so far done greater justice to the important themes of Schaff's interpretation of the American religious scene than the author of this fine book."

\section{— Klaus Penzel}

"Graham is to be commended for his splendid accomplishment in retrieving Schaff's contributions to American cultural and religious criticism."

Philip Schaff's Interpretation of Nineteenth-Century American Religion

\section{Stephen R. Graham} Foreword by Martin E. Marty

\section{— R. Scott Appleby}

ISBN 0-8028-0841-7 -291 pages $•$ Paperback $-\$ 22.00$ At your bookstore, or call 800-253-7521 FAX 616-459-6540 


\section{AMERICAN SOCIETY OF CHURCH HISTORY}

\section{Membership Information}

The American Society of Church History was founded in 1888 by Philip Schaff and a group of colleagues. It is affiliated with the American Historical Association. Its purpose is to foster interest in the history of Christianity, and its interrelationship with its cultural context by encouraging research, writing, and teaching in this discipline.

The membership of the society consists of scholars, men and women, the majority of whom serve on faculties of colleges, universities, and seminaries. Others are archivists, clergy members, professional writers, and students, or simply those who have a serious interest in church history. The society is ecumenical in character, comprising members of various religious persuasions.

In addition to Church History, a journal published quarterly, the society holds an annual meeting in conjunction with the American Historical Association and a spring meeting on the campus of a host institution. The meeting programs and the journal provide opportunities for exploring a wide variety of subjects and the exchange of thought. Membership dues entitle one to receive the journal, with its informative articles and large book review section, and attend the meetings of the society.

In order to interest younger scholars, particularly those of ethnic minorities, in the work of the society, the council has voted to offer a dues-free membership (up to two years) to all graduate students working in the area of church history at an accredited institution upon the approval of a professor who is also a member of the society.

Application for Membership

American Society of Church History

$\begin{array}{llll}\text { Name: last } & \text { first } & \text { middle }\end{array}$

\begin{tabular}{lllll}
\hline Address: & street & city & state & zip
\end{tabular}

Present institutional affiliation/Last degree earned-when and where

Signature

Professor's signature (If graduate student)

Annual dues are $\$ 40.00$, plus $\$ 10.00$ foreign postage, including Canada. Graduate students working in the area of church history with the approval and verification of a professor who is also a member of the society may join without paying a fee. Persons who have been members of the society for at least five years and are now retired from professional life may continue membership at $\$ 20.00$ per year plus $\$ 5.00$ foreign postage. Membership in the society includes a subscription to Church History. The council approves applications at its semiannual meetings.

Send to: Henry W. Bowden, P.O. Box 8517, Red Bank, NJ 07701. 
4. Issue Frequency

Quarterlyr Mar, Jun, Sep, Dec

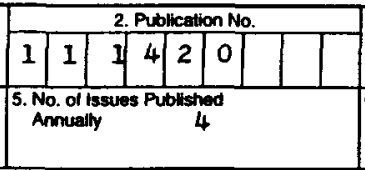

Daing Dalo 26 Sep.. 1995

6. Ammung Subacription Price $\$ 50.00$

7. Complete Mailing Address of Known Office of Publication (Street, City, County, State, and ZiP+4) Not Printer)

American Society of Church History, P.0. Box 8517, Red Bank NJ 07701

8. Complete Mailing Address of Headquarters or General Qussiness Otice of Publisher (Not Printer)

American Society of Church History, P.0. Box 8517, Red Bank NJ 07701

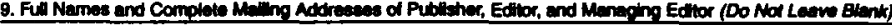
Publlsher (Name and Complote Maling Addross)

American Society of Church History, P.0. Box 8517, Red Bank N.J 07701

Editor (Name and Complote Maing Address) Martin E. Marty, Jerald C. Brauer

306 Swift Hall, 1025 E. 58 th St., Chicago IL 60637

Managing Editor (Name and Complate Mailing Address)

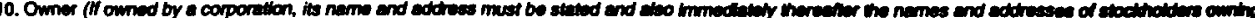

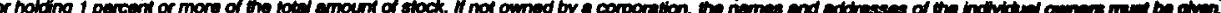

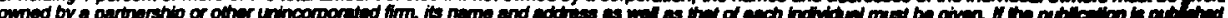

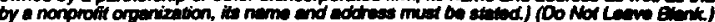

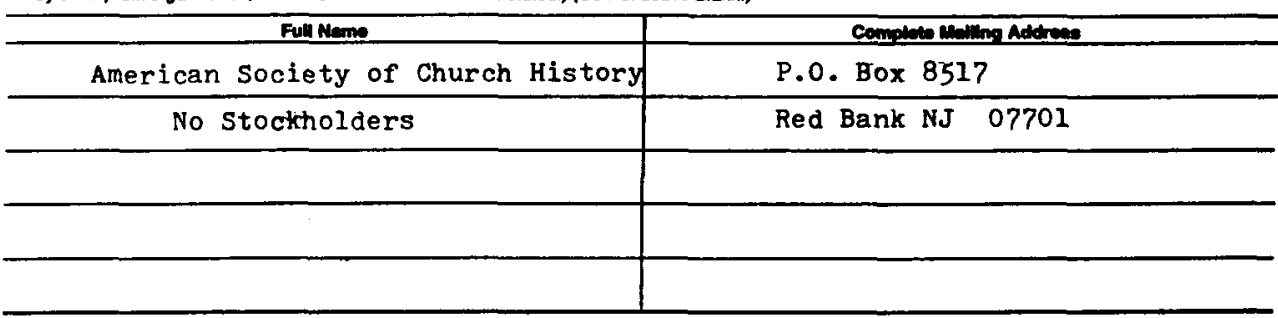

11. Known Boncholders, Mortgagees, and Other Securily Holders Owning or Holding 1 Percent or More of Total Amount of Bonds. Mortgages, or Other Secunites. II none, check here. $\square$ None

\begin{tabular}{c|c|c|}
\hline Full Nom & Complew Mamin Addreas \\
\hline None & \\
\hline & \\
\hline & \\
\hline
\end{tabular}

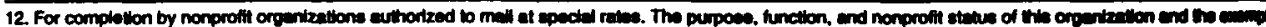
status for federed income tex puppeses: (Check one)

1. Has Not Changed Durlog Preceding 12 Monthe

$\square$ Has Changed Duitro Preceding 12 Montw

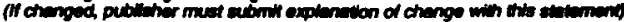

PS Form 3526, October 1894 (Soe instructions on Fiverte) 


\begin{tabular}{|c|c|c|}
\hline \multirow{2}{*}{$\begin{array}{ll}\text { 13. Fublication Name } & \text { CHURCH HISTORY } \\
\text { 15. } & \text { Extent and Neture of Circulation } \\
\end{array}$} & \multicolumn{2}{|l|}{$\begin{array}{r}\text { 14. Issue Date for Clrectation Data Betow } \\
26 \text { Se pt. , } 1995 \\
\end{array}$} \\
\hline & $\begin{array}{l}\text { Average No. Coples Each lasue } \\
\text { During Preceding } 12 \text { Months }\end{array}$ & $\begin{array}{l}\text { Actual No. Copies of Single tasue } \\
\text { Published Nowreat to Filing Date }\end{array}$ \\
\hline a. Total No. Coples (Nor Pross Aun) & 3548 & 3548 \\
\hline $\begin{array}{l}\text { b. Pald and/or Requested Clrculation } \\
\text { (1) Saleas Through Deallars and Camiers, Street Vendors, and Counter Sales } \\
\text { (Not Mallod) }\end{array}$ & None & None \\
\hline $\begin{array}{l}\text { (2) Pald or Requested Mall Subscriptions } \\
\text { (include Adventisers' Proof Copies/Exchange Copies) }\end{array}$ & 3123 & 3123 \\
\hline $\begin{array}{l}\text { c. Total Pald andfor Requested Circulation } \\
\text { (Sum of } 15 b(1) \text { and 15b(2)) }\end{array}$ & 3123 & 3123 \\
\hline $\begin{array}{l}\text { d. Free Distribution by Mali } \\
\text { (Samples, Complimentay, and Other Free) }\end{array}$ & 225 & 225 \\
\hline 6. Free Oistribution Outside the Mall (Camiers or Other Means) & None & None \\
\hline 1. Total Free Distribution (Sum of 15d and 15e) & 225 & 225 \\
\hline 9. Total Distribution (Sum of $15 \mathrm{c}$ and 15 ) & 3348 & 3348 \\
\hline $\begin{array}{l}\text { 1. Coplos Not Oistributed } \\
\text { (1) Office Use, Leltovers. Spoiled }\end{array}$ & 200 & 200 \\
\hline (2) Retum from News Agents & None & None \\
\hline Total (5um of $15 \mathrm{~g}, 15 \mathrm{~h}(1)$, and $15 \mathrm{sh}(2))$ & 3548 & 3548 \\
\hline $\begin{array}{l}\text { Drcent Pald and/or Requested Creulation } \\
15 c / 15 g \times 100)\end{array}$ & 100 & 100 \\
\hline
\end{tabular}

6. This Statement of Ownerstip will be printed in the De C 1995 bese of this publlcation. $\square$ check box if not required to publlath.

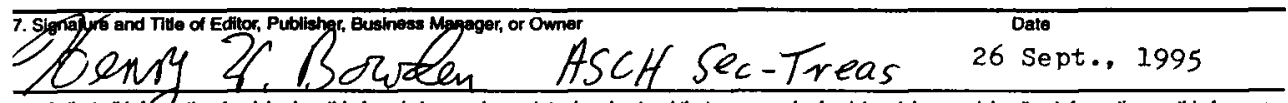

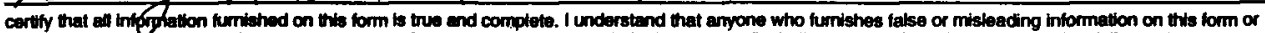

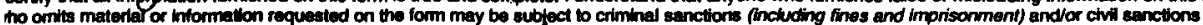
nateding multiplo demagos and chit penatios).

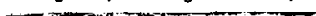

\section{Instructions to Publishers}

. Complete and file one copy of this form with your postmaster on or before October 1, annually. Keep a copy of the compieted form for your records.

Include in items 10 and 11, in cases where the stockholder or security holder is a trustee, the name of the person or corporation for whom the trustes is acting. Aleo inctude the names and addresses of individuals who are stockholders who own or hold 1 percent or more of the lotal amount of bonds, mortgages, or other securities of the publishing corporation. In liem 11, if none, check box. Use blank sheets if more space is required.

Be sure to fumish all Information calted for in item 15, reganding circulation. Free circulation must be shown in items 15d, e, and $f$.

If the publication had second-class authorization as a general or requester publication, this Statement of Ownership, Management, and Creculation must be published; it must be printed in any issue in October or the first printed issue affer October, if the pubilication is not published during October.

In item 16, inclicate date of the issue in which this Staternent of Ownershlp will be printed.

Item 17 must be stgred.

Wure to fle or publish a statement of ownership may lead to suspenston of second-class authorization.

IForm 3526, October 1094 (Aleverse) 


\title{
PLAN AHEAD
}

\author{
Winter Meeting \\ 2-5 January 1997 \\ New York, New York
}

Proposals for papers, sessions, moderators, and respondents are welcomed by the Program Committee. Send all suggestions and offers to:

\author{
Professor Barbara Brown Zikmund \\ Hartford Seminary \\ 77 Sherman Street \\ Hartford, CT 06105
}

\section{PLAN AHEAD}

\author{
Spring Meeting \\ 24-27 April 1997 \\ Vanderbilt University, Nashville, Tennessee
}

Proposals for papers, sessions, moderators, and respondents are welcomed by the Program Committee. Send all suggestions and offers to:

Professor Dale A. Johnson

Vanderbilt Divinity School

Nashville, TN 37240 